ОСОБЛИВОСТІ ПЕДАГОГІЧНОЇ ВЗАЄМОДІЇ

ВИКЛАДАЧА ТА СТУДЕНТА ЗАСОБОМ ЗМІШАНОГО НАВЧАННЯ

\title{
FEATURES OF PEDAGOGICAL INTERACTION BETWEEN TEACHER AND STUDENT VIA BLENDED LEARNING
}

У сучасних реаліях двадцять першого століття система вищої освіти в Україні безперервно підлаштовується під зміни, які відбуваються в різних сфрерах суспільного життя, таких як глобалізація, інтеграція в європейський простір, науково-технічний прогрес, зміни на ринку праці та інші. Основним завданням закладів вищої освіти стає покращення якості освіти, та, як результат, підготовка висококвалісрікованих фахівців нової формації. За основу взято концепцію створення освітнього середовища, у якому педагогічна взаємодія буде здійснюватися за межами реальних занять. Роль викладача в освітньому процесі буде змінюватися на більш демократичну, а сам викладач виступатиме ментором, або фасилітатором. Тобто освіта стане більш студентоцентрованою та враховуватиме сьогоденний суспільний запит. Сучасні студенти є більш схильними до використання інфрормаційно-комунікаційних технологій, тому наразі освітня система проходить через низку реформ. Робота присвячена аналізу особливостей змішаного навчання та їх впливу на орормування сучасного типу комунікації в педагогічній взаємодії викладача і студента. Розглянуто новітні кончепиії провадження освітньої діяльності, які можуть забезпечити результативність та ефрективність підготовки висококвалісрікованих орахівців. Досліджено сучасний стан розвитку та використання змішаного навчання в закладі вищої освіти. Проаналізовано основні модуси взаємодії учасників освітнього процесу під час профессійної підготовки. Визначено поняття змішаного навчання, основні його моделі та функції. Обірунтовано роль викладача в освітньому процесі із залученням електронних засобів навчання в разі трансформації та зміни площини взаємодії між викладачем і студентами. Висвітлено переваги та недоліки використання інфрормаційно-комунікаційних технологій в освітньому процесі та особливості педагогічної взаємодії між викладачем та студентом з використанням змішаного навчання.

Ключові слова: педагогічна взаємодія, комунікація, змішане навчання, інфрормаційнокомунікаційні технології, фрасилітація.

\section{Марчук A.A.}

аспірант кафредри педагогіки, іноземної фрілології та перекладу

Харківського національного економічного університету імені Семена Кузнеця

In the modern realities of the twenty-first century, the higher education system in Ukraine is constantly adjusting to changes occurring in different spheres of public life, such as globalization, integration into the European space, scientific and technological progress, changes at the labor market, and others. And the main task of higher education institutions is to improve the quality of education and, as a result, the training of highly qualified specialists of the brand new formation. It is based on the concept of creating an educational environment in which pedagogical interaction will take place outside offline classes. Where the role of the teacher in the educational process will change to a more democratic one, and the teacher himself will act as a mentor or a facilitator. In other words, education will become more studentcentered and take into account today's public inquiry. Today's students are more likely to use information and communication technologies, so the education system is going through a series of reforms. This paper is devoted to the analysis of the features of blended learning and their influence on the formation of modern type of communication in pedagogical interaction of teacher and student. The newest concepts of conducting educational activities that can ensure the efficiency and effectiveness of training highly qualified specialists are examined. The current state of development and use of blended learning in higher education is investigated. The basic modes of interaction of participants of educational process during vocational training are analyzed. The concept of blended learning, its main models and functions are defined. The role of the teacher in the educational process with the involvement of electronic learning in the case of transformation and change of the plane of interaction between the teacher and students is substantiated. The advantages and disadvantages of the use of information and communication technologies in the educational process and the peculiarities of pedagogical interaction between teacher and student using blended learning are highlighted. This article is devoted to the analysis of the features of blended learning and their influence on the formation of pedagogical interaction between teacher and student. The concept of blended learning, its main models and functions are considered. The role of the teacher in the educational process involving blended learning in case of transformation and change of the plane of interaction between the teacher and students is substantiated. The advantages and disadvantages of the use of information and communication technologies in the educational process are highlighted. process are highlighted.

Key words: pedagogical interaction, communication, blended learning, information and communication technologies, facilitation.
Постановка проблеми в загальному вигляді. Сучасні освітні реалії та розвиток технологій вимагають змін у ключових підходах до системи вищої освіти України. Наразі ключовим питанням є поняття якості освіти, що є невід'ємною частиною підготовки висококваліфікованих фрахівців для сучасного ринку праці. Одним із компонентів підвищення якості освіти є реалізація концепції управління педагогіч- ною взаємодією між викладачами та студентами, зокрема майбутніми менеджерами. Із розвитком інфрормаційно-комунікаційних технологій в освіті змінюються ролі педагогічної взаємодії, а саме залучається формат змішаного навчання, тому необхідним й актуальним $є$ визначення особливостей педагогічної взаємодії між викладачем і студентом при застосуванні елементів змішаного навчання. 
Аналіз останніх досліджень і публікацій. Дослідження педагогічної взаємодії та реалізації концепції змішаногонавчанняздійснювалинауковці різних країн, а саме: Н. Авшенюк, В.Андрущенко, Т.Борова, О. Гончар, , Т. Колбіна, В. Кухаренко, К. Лісецький, Є. Пасов, Є. Пьяних, Н. Рашевська, Дж. Сіменс (G. Siemens) Inman\&Kerwin, Н. Тучина, А. Фандєєва, А. Фоміна, Т. Шроль та інші. Питання змішаного навчання було розглянуто з позиції викладання навчальних дисциплін мовного спрямування.

Виділення не вирішених раніше частин загальної проблеми. Проте актуальним залишається питання визначення вектору розвитку педагогічної взаємодії між викладачем і студентом із використанням змішаного навчання.

Метою статті $є$ визначення особливостей фрормування сучасного типу комунікації в педагогічній взаємодії між викладачем та студентом у ході реалізації концепції змішаного навчання з метою підвищення вмотивованості студентів. Завдання: дослідити сучасний стан розвитку та використання змішаного навчання в закладі вищої освіти (3ВО); розглянути переваги та недоліки змішаного навчання як нового фрормату педагогічної взаємодії між викладачем і студентом у процесі професійної підготовки; визначити особливості педагогічної взаємодії між викладачем та студентом з використанням змішаного навчання.

Виклад основного матеріалу. Реформи системи освіти, глобалізація, укладення Україною різних міжнародних угод стимулюють фрормування нових підходів і розробку принципово нових критеріїв якості освіти та мають позитивний вплив на успіх студентів. Технологічний розвиток $€$ настільки динамічним і фрутуристичним, що має значний вплив на систему освіти як у світі, так і в Україні. Активно розробляються нові підходи та критерії в системі освіти, пов'язані з викладанням та процесом навчання.

Із залученням сучасних технологій виникають новітні концепції провадження освітньої діяльності, які можуть забезпечити результативність та еорективність підготовки майбутніх висококваліфрікованих фрахівців у максимально коморортних умовах. Сучасне покоління студентів $€$ найбільш орієнтованим на використання інформаційнокомунікаційних технологій. Змішаний тип навчання допоможе створити освітнє середовище, у якому взаємодія між викладачем і студентом буде виходити за межі реальних занять: освітній процес буде відбуватися як очно, так і дистанційно.

Як зазначає Г. Ткачук, особливостями закладів вищої освіти, що використовують систему змішаного навчання, є: використання спеціалізованих технологій і засобів навчання - застосування комп'ютерів, мережевих засобів, мультимедійних технологій, спеціального програмного забезпе- чення для підготовки навчальних курсів і навчання студентів; тестовий контроль якості знань - використання тестових систем на базі інфрормаційних технологій.

У зв'язку з цим змінюється фрормат взаємодії викладача зі студентами, та, як наслідок, змінюються форми і методи навчання. У системі змішаного навчання як сукупності елементів, об'єднаних постійною взаємодією для виконання функцій освітнього процесу, на думку А. Фоміної [12], важливими $€$ такі аспекти: інституційний - наявність у ЗВО стратегії розвитку електронного, зокрема змішаного, навчання; управлінсько-технологічний - організація і управління навчальним процесом, у якому поєднані традиційні фрорми й електронне навчання; педагогічний - розробка методів, моделей і навчально-методичного забезпечення освітнього процесу в електронному середовищі навчання.

Отже, виникає необхідність пошуку шляхів управління освітнім процесом у такому модусі навчання як змішане, що має на меті також отримання економічної ефрективності освіти. О. Овчарук наголошує, що економічна ефрективність - це позитивний вплив на співвідношення досягнутого результату до витрат часу, грошей та інших ресурсів на його досягнення, в порівнянні з традиційними формами навчання. Серед показників науковець виокремлює такі: гнучкість (можливість навчатися тоді, коли є час, у будь-якому місці), модульність (формування індивідуального навчального плану, що відповідає особистим потребам студентів: вибір дисциплін, дуальність - можливість поєднання навчання 3 основною професійною діяльністю), асинхронність (вибір технологій навчання, зручних для кожного студента) [8].

Ці фрактори мають вплив не тільки на зміну ієрархії освітнього процесу, а також і на роль викладача у ньому. Серед фрункцій сучасного викладача виокремлюють такі: координування освітнього процесу, корегування змісту дисципліни, консультації в ході складання індивідуального навчального плану, керівництво навчальними проектами за допомогою інформаційно-комунікаційних технологій (IKT) тощо. Зазначені фрункції для їх реалізації потребують іншої ролі викладача, ніж тільки передача знань. Фасилітація стає основною роллю викладача. Як зазначають науковці, фрасилітація є інструментом, який дозволяє ефективно організовувати роботу у групі, метою якого стає допомагати, спрямовувати та полегшувати засвоєння знань та набуття необхідних компетентностей. Т. Манн визначає основні фрункції фрасилітатора як комунікатора, а саме: спрямовувати та структурувати дискусію, визначати найбільш ефрективні рішення у дискусії групи, брати на себе ризики за результати дискусії, мати комунікативну компетентність, вмотивовувати студентів до дискусії тощо. [19]. Такі зміни зумовлюють підвищення 
вимог до студентів, де їх основною діяльністю стає самоорганізація, набуття навичок самостійної роботи та необхідної кваліфрікації.

Дослідники наголошують, що система змішаного навчання базується на світоглядних і методологічних засадах відкритості та безперервності процесу пізнання. Багато педагогів і науковців вважають, що використання сучасних технологій як інструменту сприяє навчанню студентів та задовольняє основні цілі: доступність освіти та високу якість отриманих знань [1].

Управління освітнім процесом в цілому та педагогічною взаємодією між викладачем і студентами зокрема має здійснюватися, спираючись на сукупність педагогічних принципів, таких як: цілепокладання, адаптивність, безперервність, обумовленість, взаємозв'язок, послідовність та інноваційність. Оптимальне поєднання таких принципів представляє підхід, який дозволяє створити комплекс заходів, що створюватимуть інфрормаційно-комунікаційний супровід для освітніх програм у закладах вищої освіти. Таким чином, усі етапи організації цього процесу відповідатимуть поставленим цілям та завданням та будуть мати інноваційний зміст.

До того ж різноманітність інформаційних технологій дозволяє викладачам взаємодіяти зі студентами поза традиційним підручником, розширювати доступ до знань та формувати новий підхід до вирішення завдань за допомогою різних засобів. Всесвітня мережа також дає можливість студентам і викладачам спілкуватись, працювати та ділитися цікавими ідеями з людьми з різних місць, що уможливлює новий тип управління педагогічною взаємодією у модусі студент-викладач, де управління має характер адаптивності, тобто взаємопристосування до вимог із взаємоузгодженням цілей студента та викладача на основі цифрових методів комунікації.

Розвиток комп'ютерних мережних технологій став однією 3 перспективних платформ для розвитку сучасної системи оффрлайн- та онлайннавчання, Таким чином, комп'ютерні технології стають основними для успіху концепції відкритих університетів, система яких базується на електронному навчанні(e-learning). Як зазначає Я. Сікора, у зв'язку з розвитком e-learning визначився новий напрям - змішане навчання. У зв'язку з цим, в усьому світі відбувається стрімкий розвиток індустрії зі створення програмних комплексів e-learning різної спрямованості, зокрема систем доставки контенту, організації та управління навчанням - LMS (Learning Management Systems), які об'єднують у собі інструменти адміністрування, комунікацій, оцінки знань, розробки навчальних дисциплін [9].

Змішане навчання визначається як середовище навчання, яке інтегрує технології в освітній процес разом із традиційною педагогічною практикою [5]. Нині у вітчизняній і зарубіжній термінології існують різні підходи до визначення сутності поняття змішане навчання.

Так, Д. Пейнтер визначає, що однією із форм сучасної освіти стає змішане навчання, метою якого є об'єднання традиційних фрормальних засобів навчання (роботу в аудиторіях, вивчення теоретичного матеріалу) із неформальними, наприклад, з обговоренням дискусійних питань за допомогою електронної пошти та інтернет-конференцій [21]. Р. Шанк під змішаним навчанням розуміє використання комбінації електронного та аудиторного навчання [23]. С. Моебз, С. Вейбелзах детермінують його як поєднання дистанційного і традиційного спілкування в інтегрованій навчальній діяльності [20]. С. Грехем трактує його як підхід, який інтегрує традиційне та комп'ютерно опосередковане навчання в педагогічному середовищі [16]. Також дослідник характеризує змішане навчання як поєднання навчання «обличчям до обличчя» (face-to-faceinstruction) з навчанням за допомогою комп'ютера (computer-mediatedinstruction) [16].

За визначенням вітчизняних авторів А. Стрюка, Ю. Триуса, В. Кухаренка, змішане навчання $є$ цілеспрямованим процесом здобування знань, набуття вмінь та навичок в умовах інтеграції аудиторної та позааудиторної навчальної діяльності суб'єктів освітнього процесу на основі впровадження і взаємного доповнення технологій традиційного, електронного, дистанційного та мобільного навчання за наявності самоконтролю студента за часом, місцем, маршрутами та темпом навчання [6].

Погоджуючись із зазначеними вище дослідниками та результатами дослідження сутності змішаного навчання, нами зроблено своє трактування даного феномена. Під змішаним навчанням ми розуміємо цілеспрямований, організований, інтерактивний процес взаємодії студентів та викладача, що дидактично оптимально об'єднує технології оффлайн та онлайн навчання, яке базується на інформаційно-комунікаційних технологіях й орієнтоване на індивідуальні запити студентів незалежно від їх розміщення у просторі й часі. Для реалізації змішаного навчання у викладанні й навчанні існують певні проблеми, які потребують вирішення, серед них педагогічні аспекти, стилі викладання, форми освітньої діяльності та підготовленість викладачів до нових систем викладання та оцінювання.

3 іншого боку, А. Фандєєва наголошує, що змішане навчання відноситься до руйнівних технологій, тобто таких, що повністю відходять від традиційних технологій [10]. Проте таке навчання стає персоналізованим та орієнтованим на студентів, що значно відрізняє його від традиційного [17].

У разі змін векторів навчання, змінюють і завдання, так, М. Кондакова доводить, що цей вид 
навчання вирішує такі завдання: дає можливість розширити спектр освітніх послуг для студентів за рахунок доступності та гнучкості, врахувати їхні індивідуальні освітні потреби, а також темп і ритм оволодіння навчальним матеріалом та стимулює формування суб'єктної позиції [4]. Також серед переваг дослідник зазначає підвищення мотивації, самостійності, соціальної активності, рефлексії та самоаналізу і, як наслідок, підвищує ефективність освітнього процесу в цілому. Така форма освіти також вливає на стиль педагога і забезпечує перехід від трансляції знань до інтерактивної взаємодії зі студентом, що сприяє фрормуванню процесу конструювання власних знань, персоналізує освітній процес, тобто студент самостійно визначає свої навчальні цілі, способи їх досягнення, ураховуючи власні освітні потреби, інтереси та здібності; викладач у цій ситуації є фрасилітатором [4]. Саме узгодження цілей значно впливає на процес управління взаємодією в модусі студент-викладач, робить його більш вмотивованим та продуктивним щодо фрормування професійних компетентностей.

Як підкреслює Т. Борова, якщо підґрунтям взаємовпливу суб'єктів є діалог, то відбувається комунікація, у ході якої знаходиться спільна дія, що веде до спільного вирішення завдань. Отже, діалогічна взаємодія - процес взаємовпливу суб'єктів діяльності у ході спільного вирішення завдань на комунікативній основі. Процес спільного вирішення завдань $є$ взаємовигідним, тому мотивація зростає з обох боків комунікантів. У такий спосіб відбувається внутрішній поштовх до дії, що сприяє її усвідомленню та більш продуктивному виконанню[2]. Підґрунтям навчального процесу на основі змішаного навчання повинен бути діалог. Одним із таких діалогових платорорм можна вважати Moodle. Завдяки якому стали поширюватися різні курси дистанційного навчання.

Дистанційний курс, розміщений у віртуальному навчальному середовищі забезпечує як управління навчальним процесом так і адміністрування. На базі цієї платформи не тільки висвітлюють основні навчальні матеріали, а й додаються інструменти для самоконтролю, закріплення матеріалу та інтерактивні форми взаємодії між викладачем і студентами [7].

На наш погляд, метою змішаного навчання $€$ об'єднання переваг офролайн та онлайн навчання, зокрема дистанційних фрорм, тобто створення такого середовища навчання, де студенти і викладачі зможуть у зручних для себе обставинах здійснювати процес навчання; викладач коротко пояснює навчальний матеріал і зупиняється на складних завданнях на занятті в аудиторії, інше студенти вивчають самостійно; проводяться як очні, так і онлайн консультації; студенти в аудиторії приділяють більше часу відпрацюванню практичних навичок тощо. Проте слід зауважити, що всі елементи змішаного навчання повинні контролюватися й супроводжуватися, таким чином викладачі матимуть змогу управляти та проводити моніторинг навчальних досягнень студентів, а студенти здійснювати самоконтроль та самомоніторинг.

Отже, такий тип взаємодії коригує традиційний освітній процес та потребує використання своїх стратегій управління.

Стратегії управління педагогічною взаємодією за допомогою змішаного навчання містить використання різних ролей у спільній діяльності викладача і студентів, стилів сприйняття і здійснення діяльності та керування процесом у значній мірі за рахунок питань різного призначення. Такий підхід дає можливість розширенню меж автономії студентів та концептуально змінює вектор взаємодії викладачів і студентів. Таким чином, стиль взаємодії змінюється, стає більш опосередкованим та адаптованим до сучасних освітніх вимог.

У зарубіжній і вітчизняній науці пропонуються класифрікації змішаного навчання за різними критеріями, сутність яких зводиться: до ступеня інтеграції інорормаційно-комунікаційних технологій у процес навчання; процентному співвідношенню трудомісткості аудиторної та самостійної роботи студентів у мережі; до фрорм контролю над ходом освітнього процесу.

Нині існує багато моделей змішаного навчання, серед таких, що застосовуються частіше, $€$ веб-платорорми: Blackboard, Virtual learning environment (VLE), Learning management system (LMS), Modular Object-Oriented Dynamic Learning Environment (Moodle) i Massive open online courses (MOOC). Студенти отримують доступ до відеолекцій, завдань для самостійного опрацювання та тестових матеріалів, спілкуються 3 викладачами та іншими студентами, мають змогу опрацювати додатковий матеріал із певної тематики. Звісно, що навіть за умови використання тієї самої платформи викладачі мають різні алгоритми роботи зі студентами та різні підходи до управління такою взаємодією.

Ще однією 3 найбільш поширених вважають таку модель як «Face-to-FaceDriver», при реалізації якої основна частина навчальної програми вивчається в аудиторії при безпосередній взаємодії $з$ викладачем, а електронне навчання використовується в якості доповнення до основної програми (найчастіше робота 3 електронними ресурсами організовується за комп'ютерами під час навчального заняття) [15; 17].

У моделі «Rotation» навчальний час розподілено між індивідуальним електронним навчанням і навчанням в аудиторії разом із викладачем, який може також здійснювати дистанційну підтримку при електронному навчанні. У моделі «Flex» більша частина навчальної програми засвоюється 
в умовах електронного навчання, а викладач супроводжує студентів дистанційно, для відпрацювання питань, складних у розумінні, організовує аудиторні консультації з малочисельними групами або індивідуально [13; 14; 18].

При реалізації моделі «Online Lab» навчальна програма засвоюється в умовах електронного навчання, яке організовано в аудиторіях, обладнаних комп'ютерною технікою, і супроводжується викладачем (в поєднанні 3 навчанням у традиційній фрормі) [13; 14; 18]. У межах моделі «Selfblend» студенти самостійно вибирають додаткові до основної освіти курси, що проводяться різними освітніми закладами. Отже, за таких умов форма взаємодії між викладачем і студентом обирається у залежності від тієї чи іншої моделі та в залежності від того, який тип взаємодії буде найбільш продуктивним $[13 ; 14 ; 18]$.

Таким чином, зважаючи на всі представлені програми, стає зрозумілим, що роль викладача трансформується, змінюючи свою площину на фрасилітатора, а модель освіти 3 використанням інорормаційно-комп'ютерних технологій допомагає урізноманітнити навчальний процес.

Як зазначалося вище, роль фрасилітатора може змінюватися залежно від моделі чи системи освіти, але ефективне управління базується на педагогічних принципах і має враховувати їх можливу різноманітність. Загалом, у процесі навчання фрасилітатор виконує інорормаційну та організаційну фрункції [11].

Отже, якість навчання залежить більшою мірою від компетенцій викладача, який повинен ефективно спрямовувати груповий та індивідуальний освітній процес у необхідному навчальним завданням напрямі. Фасилітатор створює оточення, в якому учасники разом визначають сутність явищ, генерують ідеї та розуміння того, що вони продукують.

Змішане навчання також і раніше використовувалося в освітньому процесі, проте його складові були більше обмежені лекціями, лабораторіями, підручниками або роздатковим матеріалом. Нині заклади освіти мають безліч підходів до навчання за вибором, зокрема синхронні й асинхронні фрормати в мережі.

Можна виділити комбінування очного та дистанційного навчання (ця форма $€$ найбільш поширеною) [17]. Навчальні матеріали та завдання можуть розміщуватися в LMS (Learning Management System), соціальних мережах типу Edmodo і створювати умови для проведення змішаного навчання та використання.

Так, наприклад, поширеним є використання «перевернутої» моделі, студенти переглядають відео-лекції поза аудиторією, вивчаючи контент в Інтернеті онлайн, а потім виконують домашнє завдання в аудиторії безпосередньо під керівництвом викладача. Також використовують змі- шування структурованого та неструктурованого навчання: структуроване навчання налагоджене в університетській і корпоративній навчальній структурі, де студент забезпечується набором заздалегідь розроблених навчальних матеріалів і певною траєкторією навчання [22].

Тоді як неструктуроване навчання відбувається за допомогою бесід, зустрічей або навіть листування електронною поштою у зручному для всіх фрорматі. Викладачі можуть відігравати роль фрасилітаторів та модераторів, забезпечуючи необхідний напрям ефективного спілкування; поєднання навчального контенту та додаткових матеріалів, які розміщені на різних платформах. Але створення курсів змішаного типу у межах наявного навчального часу та бюджету часто $є$ нездійсненним завданням, як зазначає А. Фандєєва [10].

Цю проблему вирішують розроблені методистами та викладачами курси, оскільки вони носять більш загальний характер і можуть використовуватися широкою аудиторією. Також застосування готових курсів полегшує викладачам підготовку до занять. Спільне навчання водночас допускає динамічне спілкування студентів, що призводить до обміну знаннями. Взаємодія з викладачами й однокурсниками підвищує мотивацію та дозволяє ґрунтовно засвоїти навчальний матеріал [10].

Отже, застосування змішаного навчання може стати одним із ключових засобів вирішення існуючих проблем у сорері освіти. Технології дистанційної освіти повинні стати одним із ключових засобів в організації навчання. У результаті використання змішаної фрорми навчання ми можемо значно спростити вирішення педагогічних та дидактичних питань.

ще однією 3 переваг змішаного навчання можна назвати можливість вибудовувати індивідуальну траєкторію навчання. Управління взаємодією змінюється від об'єкт-суб'єктного до суб'єкт-суб'єктного. У модусі студент-студент відбувається фрормування у студентів вмінь працювати в команді, що безпосередньо впливає на покращення клімату в навчальному середовищі, довіри та відповідальності за свої результати навчання.

Проте існують також недоліки застосування змішаного навчання: викладач витрачає більше робочого часу на підготовку матеріалів та розміщення їх на платорормах, також викладач повинен мати додаткові вміння роботи з різними методами розробки навчального матеріалу для електронного або змішаного навчання, що вимагає від нього постійного підвищення кваліфрікації.

ще одним із недоліків можна вважати складність в організації та проведенні таких занять: не завжди ЗВО мають певну технічну та аудиторну базу для таких цілей. Застосування інфрормаційно-комунікаційних технологій в якості засобів 
управління освітнім процесом пов'язане із впровадженням різних груп зовнішніх або внутрішніх програмних продуктів. Студенти також повинні витрачати на підготовку більше часу, від них вимагається підвищений рівень відповідальності за свої результати навчання, що інколи викликає нерозуміння.

Дж. Хофман виокремлює ще одну організаційну проблему, що є важливою для здійснення такого типу навчання та пов'язані із забезпеченням координації всіх елементів курсу [17].

Незважаючи на недоліки, змішане навчання поступово стає невід"ємною вимогою часу, тому необхідно вирішувати питання, які виникають із застосуванням змішаного навчання.

Як підкреслює Т. Борова, першочергову увагу необхідно приділяти розвитку і вдосконаленню навичок викладачів ЗВО орієнтуватися в інформаційному просторі, отримувати інформацію й оперувати нею задля забезпечення оптимальних умов у процесі навчання студентів, сприяти отриманню ними вищої освіти у сорері економічних відносин на максимально можливому та якісному рівні у відповідності до індивідуальних можливостей особистості із застосуванням профрільного навчання, а також згідно власних потреб і вимог сучасного високотехнологічного суспільства [3]

Як приклад, нами застосовуються на заняття 3 англійської мови у модусі «студент-викладач» такі форми спілкування, як: тематичні чати, електронна пошта, спільне використання фрайлів (технологія прямого зв'язку, яка дозволяє багатьом користувачам спільно працювати з однаковими файлами в реальному часі з відображенням результатів своїх дій на екрані, які доступні одночасно всім учасникам навчального процесу). Широко розповсюджені форуми у модусі «студент-викладач», «студентстудент». Для підготовки презентацій використовуються відеоролики з Інтернету, що дає реальну можливість вивчати на конкретних прикладах програмний матеріал. Усе це підвищує вмотивованість студентів до навчання і спрощує завдання викладачів. Інтерактивне он-лайн навчання також може відбуватися у системах «студент-студент» та «студент-комп'ютер». Таким чином, зазначені вище модуси електронного навчання $\epsilon$ ефрективними 3 позиції досягнення визначеної мети заняття, курсу тощо. За таких обставин саме змішаний тип (blended learning) навчання $€$ едективним.

Висновки. Можемо зробити висновок, що використання змішаного типу навчання допомагає перевести взаємодію між викладачем і студентами на новий, більш ефективний рівень. Змішане навчання дозволяє використовувати накопичений позитивний досвід класичного навчання з доповненням сучасних технологій. Оскільки використання інорормаційно-комп'ютерних технологій у зміша- ному навчанні відкриває широкі можливості для здійснення контрольованої самостійної роботи студентів за допомогою викладача-орасилітатора, сприяє розвитку самостійної творчої діяльності, стимулює одержання додаткових знань та їх закріплення, це дає можливість опосередковано впливати на освітній процес та готувати висококваліфрікованих конкурентоспроможних фрахівців для державного та міжнародного ринку праці.

У перспективі планується визначення критеріїв управління освітнім процесом на основі змішаного навчання, що дасть змогу оптимізувати процес залучення фрорм змішаного навчання в освітню діяльність викладача та студента.

\section{БІБЛІОГРАФІЧНИЙ СПИСОК:}

1. Андрущенко В. Філософрія освіти : навчальний посібник. / за заг. ред. В. Андрущенка, І. Передборської. Київ. : Вид-во НПУ імені М. П. Драгоманова. 2009. 329 c.

2. Борова Т., Гончар О. Особливості взаємодії викладачів та студентів у навчальному процесі. Криворізького національного університету. Педагогіка вищої та середньої шкіл. Кривий Ріг, 2015. Вип. 44, C. 306-309.

3. Борова Т. Теоретико-методичні підходи до застосування електронного навчання у вищій школі. Проблеми інженерно-педагогічної освіти. 2016. № 50-51. С. 8-19. Харків: УІПА

4. Кондакова М., Латипова Е. Смешанное обучение : ведущие образовательные технологии современности. Вестник образования. 2013. № 9 (2759). C. 54-64.

5. Кривонос О. Використання інсрормаційнокомунікаційних технологій в навчанні : навч. посібник. Житомир : Вид-во ЖДУ ім. І. Франка. 2013. 182 с.

6. Кухаренко В., Березенська С., Бугайчук К. та ін. Теорія та практика змішаного навчання. Монограсрія / за ред. В. Кухаренка. Харків : Міськдрук, НТУ ХПІ. 2016. 284 c

7. Лісецький К. Модель змішаного навчання в системі вищої освіти : матеріали II Міжнародної науково-практичної інтернет-конореренції «Міжкультурна комунікація в європейському мовному вимірі». 2015.

8. Овчарук О. Концептуальні підходи до застосування технологій відкритої освіти та дистанційного навчання в зарубіжних країнах та їх роль у процесах модернізації освіти Інформаційні технології і засоби навчання. 2006. № 1. URL: http://journal.iitta.gov.ua/ index.php/itlt/article/view/292/278.

9. Сікора Я. Реалізація змішаного навчання у вищому навчальному закладі Науковий вісник Ужгородського національного університету. Серія: Педагогіка. Соціальна робота. 2016. Вип. 2. - С. 236-239. URL: http://nbuv.gov.ua/UJRN/Nvuuped_2016_2_64.

10. Фандєєва А. Змішане навчання як технологія змін і трансформації Народна освіта. 2017. Вип. 2. С. 4-9. URL: http://nbuv.gov.ua/UJRN/ NarOsv_2017_2_3.

11. Фасилітація. URL: https://vlab.wikia.org/ru/wiki/ \%D0\%A4\%D0\%B0\%D1\%81\%D0\%B8\%D0\%BB\%D0\% B8\%D1\%82\%D0\%B0\%D1\%86\%D0\%B8\%D1\%8F. 
12. Фомина А. Смешанное обучение в вузе: институциональный, организационно-технологический и педагогический аспекты. URL: teoria-practica.ru/ rus/files/arhiv_zhurnala/.../fomina.pdf.

13. Baharun N., Porter A. Teaching statistics using a blended approach. Centre for Statistical and Survey Methodology, University of Wollongong. Working Paper 24-09. 2009. URL: http://ro.uow.edu.au/cssmwp/44.

14. Bailey J., Martin N., Schneider C. and other. Blended Learning Implementation Guide Version 2.0. Foundation for Excellence in Education. 2013. URL: http://digitallearningnow.com/site/uploads/2013/10/10/ BLIG-2.0-Final-Paper.pdf.

15. Bickerton, Ph. 7 Reasons Blended Learning is The Future of Training. URL: http://trainingstation. walkme.com/7-reasons-blendedlearning-futuretraining/.

16. Graham, C.R. (2005). Blended learning system: Definition, current trends and future direction. In: Bonk, C.J., Graham, C.R. (eds.) Handbook of Blended Learning: Global Perspectives, Local Designs, pp. 3-21. Pfeiffer, San Francisco.

17. Hofmann, J. Top 10 Challenges of Blended Learning (And Their Solutions!) URL: http://blog. insynctraining.com/top-10-challenges-ofblendedlearning.

18. Horn M.B., Staker H. The Rise of K-12 Blended learning. Innosight Institute. 2011. URL: http:// www.innosightinstitute.org/innosight/wpcontent/ uploads/2011/01/The-Rise-of-K-12-BlendedLearning. pdf.

19. Mann. T. Facilitation - a manual of models, tools and techniques for effective group work: a manual of models, tools and techniques for effective group working.

20. Moebs, S. \& Weibelzahl, S. (2006). Towards a good mix in blended learning for small and medium sized enterprises - Outline of a Delphi Study. Proceedings of the Workshop on Blended Learning and SMEs held in conjuction with the 1stEuropean Conference on Technology Enhancing Learning Crete, Greece, pp 1-6.

21. Painter D. Missed Steps Training \& Development. URL: http://www.obs.ru/ interest/publ/?thread=57.

22. Seven things you should know about flipped classrooms URL: https://net.educause.edu/ir/library/pdf/ ELI7081 pdf.

23. Virtual learning: A revolutionary approach to building a highly skilled workforce. 